
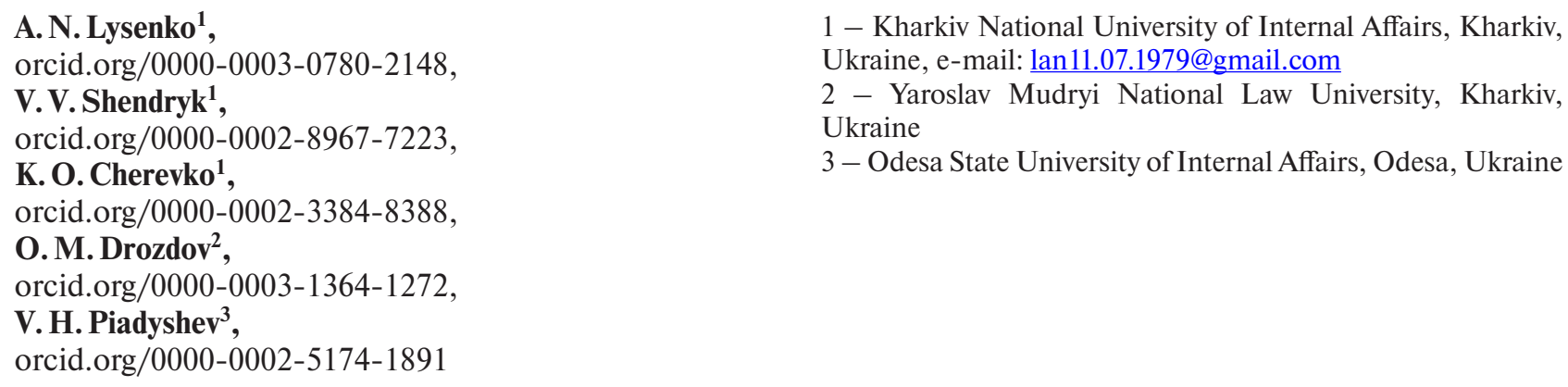

\title{
SCRAP METAL PROCUREMENT AND OPERATIONS WITH IT: TODAY'S CRIMINAL SITUATION
}

Purpose. Based on the analysis of official statistics available from the Prosecutor General's Office of Ukraine on recorded criminal offenses provided for by Art. 213 of the Criminal Code of Ukraine, to determine the practical experience of combating crime in the field of economic activities and issue-specific literature on incidence of the criminal offenses under study up to date, trends of their discovery, and causes and conditions which are conducive to such crimes.

Methodology. A system of general scientific and special methods which enabled an objective analysis of the issue under study, in particular, sociological, comparative legal, statistical analysis, logical normative, formal logical and content analysis of documents.

Findings. The findings are presented as calculated data of quantitative indicators of the dynamics in the discovery of the criminal offenses under Art. 213 of the Criminal Code of Ukraine in the period of 2014-2020, and also as a list of the main determinants of these offenses and the criminal situation related thereto.

Originality. The article proposes a number of new scientific provisions and proposals, namely, establishes the current criminal situation in the field of scrap metal procurement and operations with it in Ukraine, determines the trends of changes in it, and the major causes and conditions conducive to the criminal offenses under Art. 213 of the Criminal Code of Ukraine.

Practical value. The scientific provisions formulated and presented in this article contain specific data which are important in the general theoretical as well as in the practical sense, and also provide the ground for increasing the efficiency of law enforcement and may be used to organize the detection and investigation of violations in the procedure of scrap metal procurement and operations with it.

Keywords: scrap metal, criminal situation, law, operative search counteraction, criminal offenses

Introduction. Ukraine's gaining of independence was followed by significant transformations in its socio-economic sphere. Since 1991, as a result of denationalization of the metallurgical industry and the loss of the State's monopoly on operations with scrap metal, as well as due to imperfect legal regulation of these processes, this highly profitable area of economic activities became increasingly criminalized, with illegal scrap metal collection stations emerging on an en masse basis. Given that scrap metal is the crucial strategic and energy-saving raw material for metallurgical production impacting the performance of enterprises of the domestic metallurgical industry and contributing to environmental safety of the surroundings, there is an urgent need to reduce the crime rate relating to the issue under study.

A requisite for accomplishing this task is to increase the efficiency of operational search measures aimed at countering the criminal offenses provided for in Art. 213 of the Criminal Code of Ukraine, including by enhancing the theoretical foundations of such counteraction via a comprehensive analysis and assessment of the current criminal situation in the field of scrap metal procurement and operations with it.

Literature review. The criminal law and operational search aspects of countering the criminal offenses under Art. 213 of the Criminal Code of Ukraine were studied in the academic papers by P.N.Andrushko, V.V.Vintsuk, D.A. Harmash, V. M. Kuznetsov, A. I. Sasko, and others. The scholars primarily examined in detail the issues of criminal law regulation of these offenses, their characterization under criminal law, such its elements as perpetrator, mens rea (criminal intent), crime object, and actus reus of crime; besides, they also determined

(C) Lysenko A. N., Shendryk V.V., Cherevko K.O., Drozdov O. M., Piadyshev V. H., 2021 the target of crime, social and legal factors facilitating the violation of the procedure for operations with scrap metal, and also proposed what amendments should be made to the current Criminal Code of Ukraine to improve it, and analyzed the criteria for distinguishing the criminal offenses in this field from similar administrative offenses.

Unsolved aspects of the problem. However, a range of issues remained beyond the scholars' focus. One of them is that there is no scientific research which determines the situation with and the dynamics of violations in the procedure of scrap metal procurement and operations with it in today's Ukraine, and also the determinants conductive thereto. Nowadays, there is a particularly urgent need to study the said issues, given the high incidence rates of the criminal offenses under Art. 213 of the Criminal Code of Ukraine. Based on the foregoing, a conclusion can be made that taking into account today's tasks of operational search activities and criminalistics, further research is required on the issues of determining the criminal situation in this field of economic activities.

The purpose of the article is to form a system of knowledge about violations in the procedure of scrap metal procurement and operations with it by determining the current criminal situation in this field and the causes and conditions of the criminal offenses under study.

To achieve this goal, the following tasks should be fulfilled:

- to study the genesis of criminalization of scrap metal procurement and operations with it as a separate area;

- to analyze official statistics of the Prosecutor General's Office of Ukraine on recorded criminal offenses under Art. 213 of the Criminal Code of Ukraine, practical experience of combating crime in the field of economic activities, and issue-specific literature;

- to study the situation with and the dynamics of violations in scrap metal procurement and operations with it in Ukraine today; 
- to establish the determinants of criminal offenses under Art. 213 of the Criminal Code of Ukraine.

Methods. The following scientific methods were used to write this article: sociological method - to collect and accumulate scientific information about the object and subject matter of the research by studying official, scientific and bibliographic sources, by questionnaire survey of the National Police employees; comparative legal and statistical analysis method - to study and analyze the statistical data on countering the violations in the procedure of scrap metal procurement and operations with it; logical normative and formal logical method - to analyze the criminal situation and establish the determinants conductive to criminal offenses under Art. 213 of the Criminal Code of Ukraine; and the method of document content analysis - to study the materials of criminal cases which show the results of combating such criminal offenses.

Results. When Ukraine gained independence, the metallurgical industry was concurrently privatized and, accordingly, the State lost its monopoly on operations with scrap metal. The laws in force at that time were unable to response timely to the newly emerging processes in the field of economic activities. As a result, for many of them there was no legal regulation. Such a situation created the background for criminalization of economy.

In this respect, some scholars rightly remark: "A distinctive feature of the domestic economy is criminal monopoly on the most profitable public production areas (banking sector, fuel and energy, and mining and metallurgical industries, chemical industry, mechanical engineering, trade, and pharmaceutical industry)" [1]. The shadow processes did not remain limited to economy alone and spilled over almost to all areas of life in Ukraine. Moral harm suffered by society due to forced participation in the shadow economy had enormous scales. In the 90s of the twentieth century, the overwhelming majority of the population underwent a total change in fundamental values and orienting points, with the shadow way of life becoming a conventional thing and the authority of the State being significantly undermined in the eyes of society. Living under constraint, many citizens of the country had to disregard moral norms and took an illegal and criminal path [2].

The increasing opportunities for crime in the field of economic activities in the same period created a prerequisite for widespread illegal operations with scrap metal and keeping of illegal stations of scrap metal collection, storage and sale in the last decade of the twentieth century. These criminal offenses, when committed, involve an encroachment on the State's economic foundations and environmental safety of the surroundings. Furthermore, their social danger increases due to tax evasion on the part criminals, as this causes significant pecuniary damage to the State budget.

Thus, it is possible to affirm that after Ukraine gained independence, the criminal situation with regard to scrap metal operations deteriorated significantly.

An increased demand for scrap metal and opportunities for its unhindered sale through its illegal collection stations facilitated the emergence and widespread incidence of a new type of misappropriation - theft of metal-containing things. Its main difference from other types of theft can be identified as pre-determined intent of the perpetrator of this criminal offense to unlawfully take possession of the target of the offense with the aim of its further handing over for scrap and gaining profit for that.

The State attempted through law to stabilize the criminal situation with scrap metal procurement and operations with it in Ukraine and to establish control over this type of economic activities. To this end, in 2001 the new Criminal Code of Ukraine was adopted with introduction of Article 213, which provides for criminal liability for violation of the procedure of scrap metal operations and for organization of illegal stations of its collection, storage and sale [3].

Large-scale criminalization in the field of scrap metal procurement and operations with it is evidenced by official statistics available from the Prosecutor General's Office of Ukraine on the number of registered criminal offenses provided for by Article 213 of the Criminal Code of Ukraine and results of their pre-trial investigation, as shown in Figure. Thus, in 2014, 1287 crimes of this type were recorded, in $2015-1276$ $(-0.85 \%)$, in $2016-649(-49.14 \%)$, in $2017-661(+1.85 \%)$, in $2018-639(-3.33 \%)$, in $2019-476(-25.51 \%)$, in $2020-$ $269(-43.49 \%)[4]$.

Analyzing these data, we can conclude that throughout 2014-2015 the crime rate relating to scrap metal procurement and operations with it remained virtually unchanged. In 2016, the number of discovered criminal offenses of this type dropped down sharply - almost by half. However, a significant decrease in the effectiveness indicators of combating work in this area is due not to a reduced crime rate, but to entry into force on June 28, 2015 of the new Law of Ukraine "On Licensing of Economic Activity Types" [5]. In this Law, "activities relating to procurement, processing of ferrous and non-ferrous metal scrap and its metallurgical processing" were excluded from the list of activities subject to licensing, with appropriate amendments made to the Law of Ukraine "On Scrap Metal" [6]. In this connection, changes were made to Art. 213 of the Criminal Code of Ukraine as regards decriminalization of such a form of the criminal offenses under study as scrap metal operations performed without obtaining the license.

Moreover, with a view to bringing the provisions which regulate liability for violations relating to scrap metal operations into compliance with the new provisions of the legislation, the legislator amended Art. 213 of the Criminal Code of Ukraine in respect of determining the perpetrators who commit the criminal offenses provided for by this article [7]. In this regard a mistake was made, and thus in Art. 213 of the Criminal Code of Ukraine a provision appeared which did not comply with the rules of current laws, could not be implemented and resulted in law enforcement problems. In the change under consideration, the said article specified such perpetrator violating the scrap metal operations procedure as an official of a business entity, where information about the latter is not included in the list of business entities which carry out operations with scrap metal. At the same time, neither the Law of Ukraine "On Licensing of Economic Activity Types" nor the

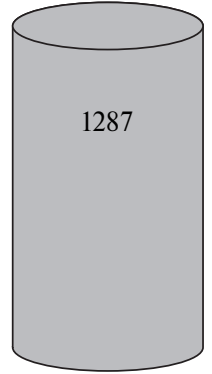

2014

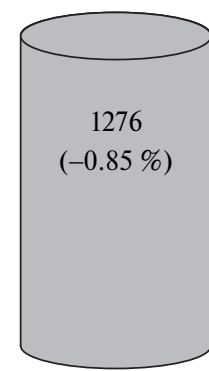

2015

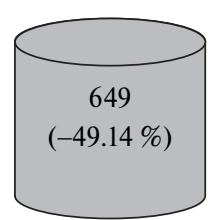

2016

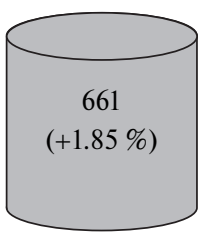

2017

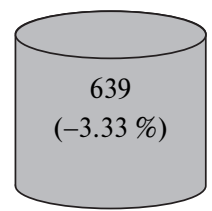

2018

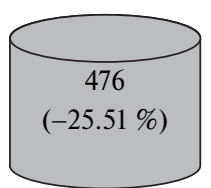

2019

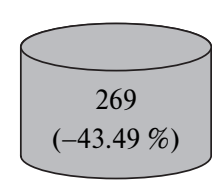

2020

Fig. Diagram of registered criminal offenses provided for by Article 213 of the Criminal Code of Ukraine 
Law of Ukraine "On Scrap Metal" (which is a special legislative act that regulates the relations arising in the course of operations with scrap metal) do not provide for the existence or the need to create the mentioned list, or the authorities with responsibility to keep it, or the requirements to business entities to be included on the list, and so on.

This change was in effect from April 5, 2015 (the date of entry into force by the Law of Ukraine "On Amendments to Certain Legislative Acts of Ukraine to Simplify the Conditions of Doing Business (Deregulation)" [7], until it was revoked on November 14, 2020, due to the adoption of the Law of Ukraine "On Amendments to Certain Legislative Acts of Ukraine to Unshadow the Metallurgical Raw Materials Market and Scrap Metal Operations" [8] and had a negative impact on the dynamics of discovery of the criminal offenses under Article 213 of the Criminal Code of Ukraine. Thus, starting from 2017 and till 2020, there is a further significant drop in the number of discovered criminal offenses under Article 213 of the Criminal Code of Ukraine - by $58 \%$. Therefore, the officially registered crime rate of scrap metal procurement and operations with it dropped by $79.1 \%$, as compared to 2014 . On the one part, this is an indication of the State's attempt to stabilize the criminal situation in this field and, on the other part, demonstrates an imperfection of criminal laws establishing liability for violation of the procedure for scrap metal procurement and operations with it, which were in force in the period under review.

However, the incidence of the criminal offenses under study is still high. By analyzing statistical data on all types of criminal offenses recorded in the field of economic activities, we established that violation of the procedure for scrap metal procurement and operations with it is one of the most widespread criminal offenses in this field, accounting for, on average, about $10.8 \%$ of total crimes for the period under study. This is confirmed by the analysis of official statistics available from the Prosecutor General's Office of Ukraine on the number of registered criminal offenses relating to economic activities and results of their pre-trial investigation. Thus, in 2014, 8418 criminal offenses of all types relating to economic activities were recorded. In this context, criminal offenses under Art. 213 of the Criminal Code of Ukraine accounted for $15.29 \%$ of their total. Accordingly, in $2015-7631$ (16.72\%), in $2016-6490(10 \%)$, in $2017-6297(10.5 \%)$, in $2018-$ $6334(10.09 \%)$, in $2019-5947(8 \%)$, and in $2020-5342$ $(5.04 \%)[4]$.

It should be noted that in actual reality the incidence of the criminal offenses under study has even higher indicators of the number of these crimes. This statement ensues from the fact that criminal offenses under Art. 213 of the Criminal Code of Ukraine are characterized by a high degree of latency. In this connection, a significant number of such crimes are not discovered by law enforcement agencies. This fact makes it impossible to establish the true criminal situation as regards scrap metal procurement and operations with it in Ukraine. This, in turn, brings about the absence of appropriate response measures on the part of the State.

It is worth noting that the vagueness of goals and objectives, as regards the choice of means and lines of the State policy on combating the violations in the procedure for scrap metal procurement and operations with it, indicates that no scientifically based approach is used to resolve this problem, thus complicating the operation of law enforcement agencies in combating crimes of this type and, consequently, creating favorable conditions for the spread of crime.

We believe that with the aim of stabilizing the criminal situation and reducing the rates of crime associated with violation of the procedure for scrap metal procurement and operations with it, there is a need to identify and eliminate respective crime determinants. Determinants of crime (from the Latin determinare - "to determine") are the sets of social phenomena which, by their joint action, induce crime. The causes of crime and its conditions are singled out as such determinants.
The causes and conditions of crime work together: a cause gives rise to an effect only when certain conditions exist.

In this regard, criminologists note that the phenomenon of crime as a system of activities at the level of society, social groups and individuals does not emerge by itself. This phenomenon rests upon its own grounds represented by other events, phenomena, and processes that have generated them under certain conditions. Such grounds are the causes. A cause in its static state by itself does not engender anything. For a consequence to emerge (for actualization of a cause in dynamics), it should be combined with a condition [9]. Besides, scholars quite rightly argue that the causes are most often represented by the circumstances under which an individual was educated in terms of morals, and his or her motivational attitudes were formed. And the conditions facilitating the commission of a crime include the conditions under which an individual's personal and other individual properties are actualized [10]. The causes of crime have a decisive influence on the decision to commit an illegal act. At the same time, there is no cause of crime which could be marked out as a major cause, since an individual's decision to become a criminal is generally influenced by all such causes together.

The conditions of crime are a set of negative phenomena and processes which facilitate the generation and actualization of the causes of crime [9]. Therefore, a condition of crime is something that does not in itself give rise to a particular crime or criminal activities, but has an impact on the processes of its generation and is involved in the determination of crime. Depending on their functional role, the conditions are divided into necessary and sufficient ones. Necessary conditions mean unfavorable conditions of life and socialization of different population strata, negative phenomena and processes which influence in such a way that bring about criminogenic deformations of public consciousness elements. For a criminal intent to be actualized there should also be sufficient conditions which reduce the risk of criminal liability and increase the chances of achieving the final result [9]. Within the framework of our research, the latter could include liberalization of criminal liability for committing criminal offenses under Art. 213 of the Criminal Code of Ukraine, low level of combating crime, corruption of law enforcement agencies and judicial bodies, and so on.

Unlike a condition, a cause is always directly related to the result, it is not separated from it by indirect links. This, in particular, means that the cause of an individual's action is his or her consciousness and will; therefore, an obvious criminological conclusion follows: the causes of crime lie in the subjective sphere of life of society, social group and personality [11].

It would be expedient to divide the crime determinants into two groups: the first group is common causes and conditions which have an influence on the growth of the rate of committed criminal offenses and, accordingly, on deterioration of the criminal situation in Ukraine; the second group is special determinants which have a direct effect on the commission of criminal offenses under Art. 213 of the Criminal Code of Ukraine. Both groups of causes and conditions are closely interrelated.

The common determinants of crime include: hard-pressing economic situation in the country and the resulting unemployment; spread of drug addiction and alcoholism; the cult of enrichment formed in society and the aspiration to lead financially secured life; growing levels of social inequality between different strata of society, and others.

Having briefly reviewed the main determinants of crime, let us move on to a detailed study on the determinants which have a direct impact on the growing rate of violations in the procedure for scrap metal procurement and operations with it, which are of greater importance for our study.

One of the major causes for which the criminal offenses under Art. 213 of the Criminal Code of Ukraine are committed is the possibility to get significant pecuniary income by illegal means. A simple mechanism via which criminal offenses of this type can be committed is a prerequisite for this. And in 
this connection, to get high profits quickly, criminals do not need to have large initial capital or special skills, or to hold a certain position, have an education degree, criminal connections or experience. It should be noted that the mechanism of implementing illegal operations with scrap metal is completely identical to the technological process according to which operations with scrap metal are made at legal enterprises, with the only difference that in the first case it is performed without being registered by the State.

The second weightiest determinant of the spread of crime associated with violation of the procedure for scrap metal procurement and operations with it is early withdrawal of the State's monopoly on such operations, which resulted in the State's actual loss of the ability to control and influence the processes occurring in this domain. This, in turn, gave rise to many negative phenomena. Thus, since 1992, when the process of privatization of metallurgical enterprises was launched, the prices for metal products have been rapidly growing (as compared with the prices existing at the times of the USSR), and this engendered commercial demand for scrap metal as the main raw material to manufacture such products. The growing prices for scrap metal and, respectively, its increased liquidity, put it in the focus of attention of criminals and caused an increase in the rate of crimes committed in connection with its turnover. As a consequence, a significant share of the State's revenues from scrap metal operations was lost, thus causing a significant pecuniary damage to the State.

The process of transition of metallurgical enterprises from ownership by the State to private ownership under conditions of emergence of the new market economy system entailed a long period of time during which there was a legal "vacuum" in the domain of economy, i.e., the laws actually did not keep pace with intense development of economic relations. In this connection, we should also mind that the legislator had no experience in the development and adoption of efficient and working regulatory legal acts under the new conditions, as well as that there was no clearly formulated strategy of the State concerning the status of business entities and the procedure under which they should operate. This led to the absence of legal regulation of some processes in the field of economic activities, including operations with scrap metal.

Imperfect legal regulation of activities related to implementation of operations with scrap metal triggered intense development of crime in this field; particularly, it consisted in the absence of a ban on exporting non-ferrous and alloyed metal scrap until 1999, and also in the absence of criminal liability for such crimes until 2001. This negative phenomenon made it impossible to effectively combat illegal operations with scrap metal in that period, and this was availed of by criminals.

Furthermore, in our opinion, another shortcoming of legal regulation is liberalization of criminal liability for the criminal offenses provided for in Article 213 of the Criminal Code of Ukraine, namely, the punishment is rather mild, given the social danger of such crimes. It should be noted that for the persons committing violations of the procedure for scrap metal operations, the fact of a relatively mild degree of criminal liability along with significant illegal revenues is of great importance when they decide on starting criminal activities [12]. In this regard, we believe that it would be expedient to make liability for commission of these criminal offenses more severe.

The wide-spread incidence of criminal offenses under Art. 213 of the Criminal Code of Ukraine is facilitated by a high level of corruption in law enforcement agencies. This is indirectly confirmed by two facts. Firstly, the mechanism of violation of the procedure for scrap metal procurement and operations with it involves forming of a large circle of persons aware of illegal collection of scrap metal, and makes these criminal offenses actually obvious. Thus, to arrange the smooth process of buying up scrap metal, criminals have to advertise their illegal activities to society by publishing respective ads. Accordingly, in such a situation illegal stations of scrap metal collec- tion, storage and sale would not be able to operate for any significant period of time without "support" via corruption connections. Secondly, today, despite the measures taken by law enforcement agencies to counteract the criminal offenses provided for in Article 213 of the Criminal Code of Ukraine, illegal stations of scrap metal collection, storage and sale operate almost in every locality of Ukraine.

The above determinants in their entirety have created favorable conditions for the emergence and spread of violations of the procedure for scrap metal procurement and operations with it, and this was immediately availed of by individual criminals as well as by organized crime members.

Conclusions. As evidenced by the analysis of the criminal situation relating to scrap metal procurement and operations with it in Ukraine, today, despite the measures which the State has implemented to stabilize it, the criminal offenses provided for by Article 213 of the Criminal Code of Ukraine are still very high in incidence ratings. The fact of their wide-spread incidence is evidenced by the analysis of the statistical data available from the Prosecutor General's Office of Ukraine on the number of registered criminal offenses in the field of economic activities. Thus, in the period from 2014 to 2020 the number of registered criminal offenses under Article 213 of the Criminal Code of Ukraine decreased by $79.1 \%$, which is primarily due to decriminalization of such a form in which they are committed as making of operations with scrap metal without an obtained license, and also due to the legislator's mistakes as to how the perpetrator of this crime is determined in this article (the changes were in effect from 05.04.2015 to 14.11.2020). At the same time, the criminal offenses under study are among the most widespread crimes in the field of economic activities, on average accounting for about $10.8 \%$ of their total number in the period under study.

We believe that the main determinants of the criminal offenses provided for by Article 213 of the Criminal Code of Ukraine and the criminal situation in Ukraine related thereto are: a) high profits, which means that criminals who perform illegal operations with scrap metal are able to get considerable revenues in the context of a relatively low severity of criminal liability as compared with other profit-motivated crimes; b) a simple mechanism for committing these criminal offenses, since criminals can get considerable pecuniary income without the need to have large initial capital or special skills, or to hold a certain position, have an education degree, criminal connections or experience; c) early termination of the State's monopoly on operations with scrap metal due to privatization of enterprises and a resulting generation of commercial demand for it in the domestic and foreign sales markets, which made scrap metal a target of encroachment by criminals; d) imperfect legal regulation of the process of operations with scrap metal, especially at the initial stage of Ukraine's independence, particularly, the absence of a ban on export of scrap metal of non-ferrous and alloyed metals (until 1999), no criminal liability for violation of the procedure for operations with scrap metal (until 2001), and liberalization of criminal liability for these crimes; e) corruption in law enforcement agencies which is due to a low level of their financial situation, combined with high profits from criminal activities involving violation of the procedure for scrap metal procurement and operations with it.

\section{References.}

1. Holovkin, B. M. (2014). General Characteristics of the Determinants of Crime in Ukraine. Forum of law, 1, 106-111. Retrieved from http://nbuv.gov.ua/UJRN/FP index.htm_2014_1_21.

2. Piasetska-Ustych, S. V. (2016). Corruption and the shadow economy in the system of socio-economic relations of society. Global and national problems of economics, 10, 34-39.

3. Verkhovna Rada of Ukraine. Legislation of Ukraine (n.d.). Criminal Code of Ukraine: Law of Ukraine dated 05.04.2001 No. 2341-III. Retrieved from https://zakon.rada.gov.ua/laws/show/2341-14\#Text. 4. Prosecutor General's Office of Ukraine (n.d.). Official website: Statistics - Prosecutor General's Office. Retrieved from https://www.gp. gov.ua/ua/1stat. 
5. Verkhovna Rada of Ukraine. Legislation of Ukraine (n.d.). About licensing of types of economic activity: Law of Ukraine dated 02.03.2015 No. 222-VIII. Retrieved from https://zakon.rada.gov.ua/laws/ show/222-19\#Text.

6. Verkhovna Rada of Ukraine. Legislation of Ukraine (n.d.). About scrap metal: Law of Ukraine dated 05.05.1999 No. 619-XIV. Retrieved from https://zakon.rada.gov.ua/laws/show/619-14\#Text.

7. Verkhovna Rada of Ukraine. Legislation of Ukraine (n.d.). On amendments to some legislative acts of Ukraine to simplify the conditions for doing business (deregulation): Law of Ukraine dated 12.02.2015 No. 191-VIII. Retrieved from https://zakon.rada.gov.ua/laws/show/191-19\#Text.

8. Verkhovna Rada of Ukraine. Legislation of Ukraine (n.d.). On amendments to some legislative acts of Ukraine concerning de-shadowing of the market of metallurgical raw materials and operations with scrap metal: Law of Ukraine dated 14.07.2020 No. 776-IX. Retrieved from https://zakon.rada.gov.ua/laws/show/776-20\#Text.

9. Holovkin, B. M. (2014). Causality in system determinations to criminality. Theory and practice of jurisprudence, 1(5), 268-275.

10. Semeniuk, O. (2017). Causes and conditions of crime and their reflection motivations of criminal behavior. Legal Ukraine, 2-3, 75-84. 11. Osmolian, V.A. (2015). Law enforcement activity on liquidation reasons for committing crimes. Scientific Bulletin of Lviv State University of Internal Affairs, (3), 148-159.

12. Lysenko, A. M., Vintsuk, V.V., Vinakov, A.V., Hrabazii, I.A., \& Shendryk, V.V. (2013). Activity of operative divisions of law-enforcement bodies concerning struggle against infringements of the order of implementation of operations with scrap metal: monograph. Kharkiv: Oberih.

\section{Здійснення заготівлі металобрухту та операцій із ним: сучасна криміногенна обстановка}

\author{
А. М. Лисенко ${ }^{1}$, В. В. Шендрик $\kappa^{1}$, К. О. Черевко ${ }^{1}$, \\ О.М. Дроздов ${ }^{2}$, В. Г. Пядишев ${ }^{3}$
}

1 - Харківський національний університет внутрішніх справ, м. Харків, Україна, e-mail: lan11.07.1979@gmail.com 2 - Національний юридичний університет імені Ярослава Мудрого, м. Харків, Україна

3 - Одеський державний університет внутрішніх справ, м. Одеса, Україна
Мета. Визначення на основі аналізу офіційних статистичних даних Генеральної прокуратури України з обліку кримінальних правопорушень, передбачених ст. 213 КК України, практичного досвіду боротьби зі злочинністю у сфері господарської діяльності та спеціальної літератури поширеності досліджуваних кримінальних правопорушень на теперішній час, тенденцій їх виявлення, причин і умов, що сприяють їх вчиненню.

Методика. Система загальнонаукових і спеціальних методів, що забезпечили об'єктивний аналіз досліджуваного предмета, зокрема, соціологічний, порівняльноправовий, статистичного аналізу, логіко-нормативний, формально-логічний і контент-аналіз документів.

Результати. Представлені у вигляді розрахункових даних кількісних показників динаміки виявлення кримінальних правопорушень, передбачених ст. 213 КК України, у період 2014-2020 рр., а також переліку основних детермінант даних правопорушень і стану пов'язаної $з$ цим криміногенної обстановки.

Наукова новизна. У роботі запропоновано ряд нових наукових положень і пропозицій, а саме: визначено сучасний стан криміногенної обстановки у сфері здійснення заготівлі металобрухту та операцій із ним в Україні, тенденції іiі зміни, основні причини та умови, що сприяють вчиненню кримінальних правопорушень, передбачених ст. 213 КК України.

Практична значимість. Сформульовані й викладені в роботі наукові положення містять конкретні дані, що мають як загальнотеоретичне, так і практичне значення, $€$ основою для підвищення ефективності правоохоронної діяльності та можуть бути використані при організації розкриття й розслідування порушень порядку здійснення заготівлі металобрухту та операцій із ним.

Ключові слова: металобрухт, криміногенна обстанов$\kappa a$, закон, оперативно-розшукова протидія, кримінальні правопорушення

Recommended for publication by O. O. Knyzhenko, Doctor of Juridical Sciences. The manuscript was submitted 01.02.21. 